\title{
Prediction of Change Management Through the Use of Information Technology Components in the Ministry of Sports and Youth of the Islamic Republic of Iran
}

\author{
Farideh Ashraf Ganjoei ${ }^{1}$, Samaneh Yarmohammadi ${ }^{2}$ Ali Zarei ${ }^{3}$
}

1. Farideh Ashraf Ganjoei, (Ph.D) Islamic Azad University, Central Tehran Branch, Iran

2. Samaneh Yarmohammadi, (Ph.D Student) Islamic Azad University, Central Tehran Branch, Iran

3. 2Ali Zarei, (Ph.D) Islamic Azad University, Central Tehran Branch, Iran

\section{ARTICLE INFO}

Received July 2017

Accepted July 2018

\section{KEYWORDS:}

Change Management

Applied Components

Information Technology

CITE:

Ashraf Ganjoei, Yarmohamadi, Zarei, Prediction of Change Management Through the Use of Information Technology Components in the Ministry of Sports and Youth of the Islamic

Republic of Iran, Research in sport management \& motor behavior, 2020: $9(18): 92-110$

\section{ABSTRACT}

The purpose of this study is to predict the management of change through the use of information technology components in the Ministry of Sports and Youth of the Islamic Republic of Iran. To collect data, a questionnaire was used to survey the acceptance and use of information technology in the workplace (Davis, 1989) in four sections: perceived usefulness with 6 questions, perceptual ease with 6 questions, attitude towards the use of information technology with 5 questions, and The tendency to use information technology with 4 questions and a total of 21 questions of five values (Likert number 1 to 5, too many) were used and the AdCaracy FAQ changed the management to assess the extent and the extent to which employees were exposed to changes in the workplace to measure The components of knowledge, desire, knowledge, ability, and reinforcement (Likert Five Value Questionnaire). The questionnaire from the translated translated article is a research article to investigate the extent and staff resistance to change (Boehne, 2012). It is worth mentioning that the questionnaire is a super standard and international, and with the confirmation of professors, Is. Its reliability has been approved and certified at an international level of $96 \%$. The methodology of this research is descriptive-survey. The results of the research were descriptive and inferential statistics such as Kalmogorov-Smirnov (to determine the normality of the data), single-sample t-test (to determine the status of the main variables), Pearson correlation coefficient (to determine the relationships between variables), multiple regression test (forward direction Nasal variables) were analyzed using spss software. The results showed that there is a significant relationship between "change management" and "application of information technology". Also, there is a significant positive relationship between "perceived usefulness", "perceived ease", "attitude toward application" and "tendency to use" with "change management" ( $p<0.05)$., So it can be deduced that change management can be predicted through the IT component. In this research, change management is considered as a criterion variable and is predicted through the application of information technology components. 


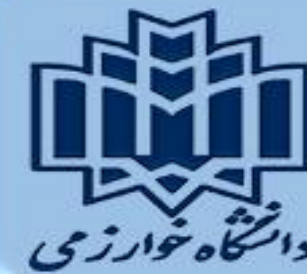

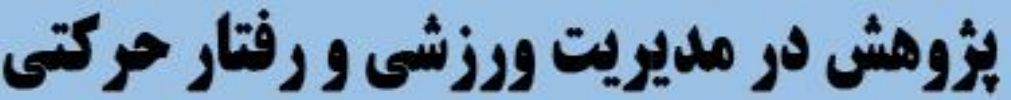

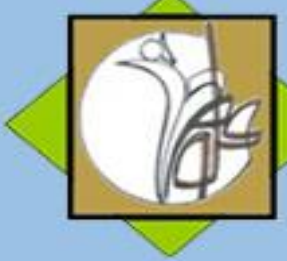

\section{بيش بينى مديريت تغيير از طريق مولفه هاى كاربرد فناورى اطلاعات در وزارت ورزش و جوانان جمهورى اسلامى ايران}

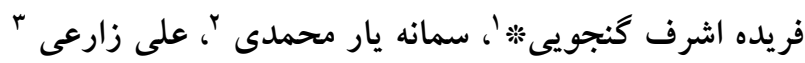

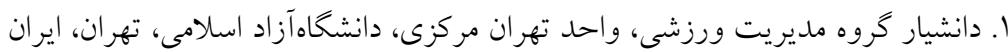

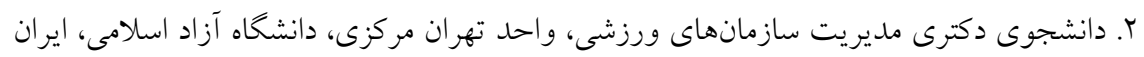

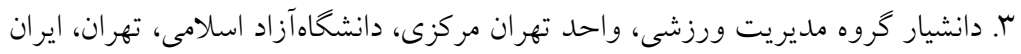

\begin{abstract}
Ours?
هدف از تحقيق حاضر بيشبينى مديريت تغيير از طريق مؤلفهاى كاربرد فناورى اطلاعات در وزارت ورزش و جوانان جمهورى اسلامى ايران است. جهت گردآورى دادهها از برسشنامه تم براى بررسى ميزان بذيرش و استفاده از فناورى اطلاعات در محيط كار (ديويس،9191) در جهار بخش سودمندى ادراكى با 7 سؤال، سهولت ادراكى با 7 سؤال، نخرش نسبت به كاربرد فناورى اطلاعات با ه سؤال و تمايل به استفاده از فناورى اطلاعات با ع سؤال و درمجموع اب سؤال ينج ارزشى (ليكرت عدد ا خيلى كم تا عدد ه خيلى زياد) مورداستفاده قرار كرفت و برسشنامه ادكاريا مديريت تغيير براى بررسى ميزان و موارد مقاومت كاركنان در برابر تغيير در محيط كار براى سنجش مؤلفههاى آكاهى، تمايل، دانش، توانايى و تقويت (برسشنامه ينج ارزشى ليكرت) است. يرسشنامه موردنظر از بركرفته ترجمهشده مقاله بزّوهشى براى بررسى

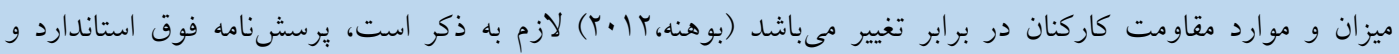
بين المللى مىباشد و با تأييد استادان مجدداً روايى لازم را كسب كرده است. يايايى آن نيز در سطح بين المللى آلفاى 97/. كسبكرده و مورد تأييد قراركرفته است. روش شناسى اين تحقيق از نوع توصيفى - ييمايشى است. نتايح يزوهش از طريق آمار توصيفى و استباطى مانند كالموكروف- اسميرنف (جهت تعيين نرمال بودن دادهها)، آزمون t تك نمونه اى (جهت تعيين وضعيت متغيرهاى اصلى)، ضريب همبستخى بيرسون (براى تعيين روابط بين متغيرها)، آزمون ركرسيون جندكانه (جهت بيش بينى متغيرها) با استفاده از نرم افزار SPSS مورد تحليل قرار كرفت. نتايج نشان داد كه ارتباط معنىدارى بين (مديريت تغيير)" و (كاربرد فناورى اطلاعات)) مشاهده مىشود. همجنين ارتباط مثبت معنىدارى بين (سودمندى ادراى شده))،

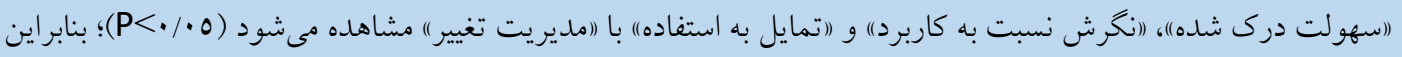
مى توان اينخونه استنباط كرد كه از طريق مؤلفه فناورى اطلاعات مى توان مديريت تغيير را بيش بينى نمود. در اين تحقيق مديريت تغيير به صورت متغير ملاكى مد نظر قرار كرفته و از طريق مؤلفه هاى كاربرد فناورى اطلاعات مورد بيش بينى
\end{abstract} قرار كرفته است.
اطلاعات مقاله: دريافت مقاله تير ه7ه يذيرش مقاله تير MوM

ثقويسنده مسئول: ganjouei@yahoo.com

وازه هاى كليدى:

ملديريت تغيير مولفه هاى كاربردى

فناورى اطلاعات

الرجاع:

اشرف گنجويى، يارمحمدى، زارعى. بيش بينى مديريت تغيير از طريت مولفه هاى كاربرد فناورى اطلاعات در وزارت ورزش و جوانان جمهورى اسلامى ايران. يُزوهش در مديريت ورزشى و رفتار حركتى، $11 \cdot-9 r: 1 r q 1$ 


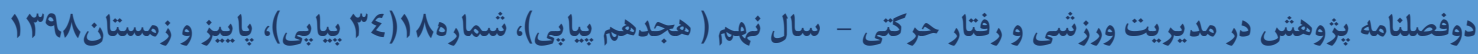

مقدمه

امروزه مديران با آكاهى كامل سازمانهاى خود را در معرض تغيير و توسعه درزمينه هاى خط مشى، ساختار و رفتارهاى انسانى و مهم ترين آن فناورى اطلاعات قرار مىدهند يكى از مهمترين جنبههاى تغيير، تغيير در بهكاركيرى و استفاده از فناورى بهويزه فناورى اطلاعات است كه در بيشتر مواقع با مقاومت در بهكار گيرى توسط منابع انسانى مواجهه مىشود و ييادهسازى مديريت تغيير در سازمانها را با اشكال روبرو مىنمايد (1). همجنين دردنياى كنونى شاهد آن هستيم كه تغييرات سازمانى و اجتماعى بهسرعت در حال افزايش است بنابراين ضرورى به نظر مىرسد كه سازمانهاى ورزشى جهت حفظ بقاء در جنين محيطهاى يرتلاطمى تغييراتى را در خود ايجاد كنند (Y)؛ اما هنگام اعمال تغييرات در بسيارى از سازمانها مقاومتهايى صورت مى كيرد و در بسيارى از موارد مشاهده مى شود برخى از افراد حتى در مقابل تغييراتى كه خوب و منطقى به نظر مى رسند نيز مقاومت مى كنند در نتيجه اجراى يك تغيير سازمانى آن هم با موفقيت مستلزم تعهد مديريت، برنامه اجر ايى مناسب و موافقت و حمايت از سوى تمام كاركنان در آن سازمان مى باشد همجنين مديريت تغيير خط مشى است كه نحوه آمادهازى، مجهز كردن و حمايت از افراد جهت سازگارى موفق با تغييرات را فراهم مى كند تا موفقيت سازمانى حاصل گردد (·(Y)(YN). دو دليل عمده وجود دارد كه ضرورت تغيير در سازمانها را ايجاب مىنمايد نخست نياز به تغييرات درونى براى تطبيق با رخ دادهاى ايجاد شده در خارج از سازمان و در مرحله بعد علاقه به بيشبينى توسعه در آينده و يافتن راه هاى تطبيق با آن به هنگام حادث شدن تغيير (rا). مقاومت افراد در مقابل تغيير يكى از مهمترين مسائل سازمان ها و بنگاه هاى اقتصادى است زيرا آنها تغيير را نوعى تهديد براى خود مىدانند و به سادكى بذيراى تحولات و تغييرات نمىشوند و غلبه بر اين مقاومت و هدايت آن، يكى از مشكل ترين وظايف مديران

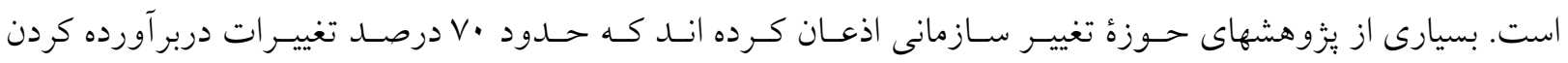
اهداف سازمانها با شكست مواجه مـيشـود (YN). در دنيـاى كنـونى ماهيـت محسيط وتقاضاى بازار به طور اساسى

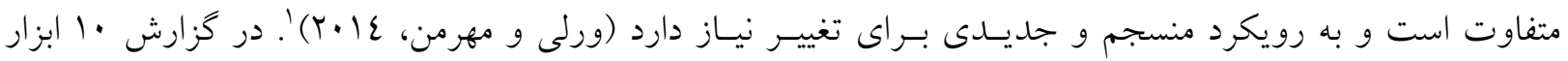

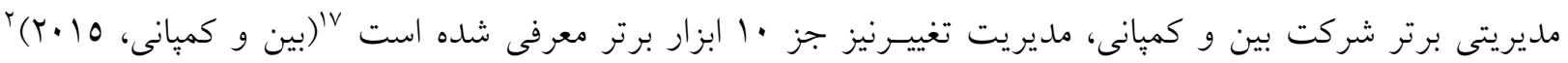

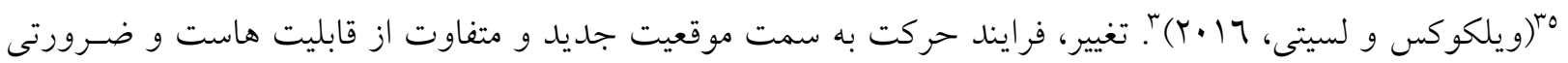

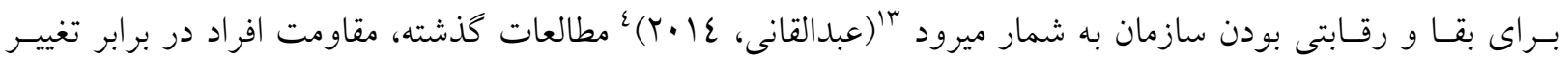
را مانع اساسى درييادهسازى تغيير بيان كردهانـــ. مفهـوم مقاومـت در برابـر تغييـر، از مــل تغييـرسازمانى خروج از انجماد، انتقال و انجماد كرت لوين (19عV) ريشه كرفته است كه بيان مسى كنــ نيروهاى محر كه اى وجود دارد كه ميتواند

1. Worley \& Mohrman (2014)

${ }^{2}$.Bain \& Company(2015)

${ }^{3}$.Willcocks \& Lacity(2016)

${ }^{4}$.Abdelghani(2014) 


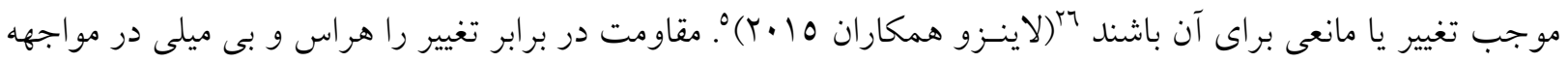
بـا تغييـرمعرفى كرده اند وآمادكى تغيير عامل ضرورى براى به حداقل رساندن مقاومـت در برابـر تغييـر اسـت • (روسلى

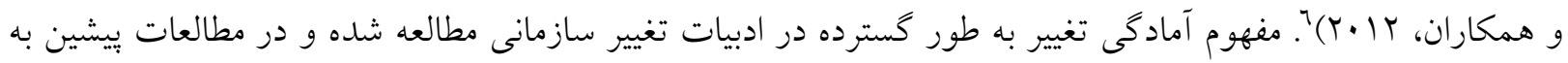
عنوان باورى كه واكنش نسبت به تغيير را در مراحل ابتدايى فراينـدمديريت تغيير تحت تأثير قرار ميدهد، مفهوم سازى شده است. آمادكى تغيير نشـاندهنـدهُ حركـت مثبت بسمت بياده سازى تغييروشكل دهنده باورهاوقابليتها براى اعمال

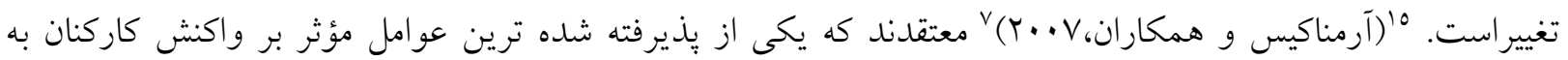
تغيير، باور آنهاسـت كـهـ آمـادگى سـازمان براى تغيير را به همراه دارد. آنها دريافتند كه يــنج عامـل كليـدى بـراى سـنش ميـزان تمايسل يذّيرندكان تغيير سازمانى وجود دارد كه عبارت اند از: اختلاف (باور به ضـرورت تغييـر)، تناسـب (باور به اينكه براى برطرف كردن اختلاف بين وضع موجود و مطلوب، تغيير خاصى مناسب است) كارآمدى (قابليت درى شده براى يياده سازى تغيير)، يشتيبانى اصولى) حمايت واحدهاى تغييـر ورهبران ايده تغيير و سودمندى

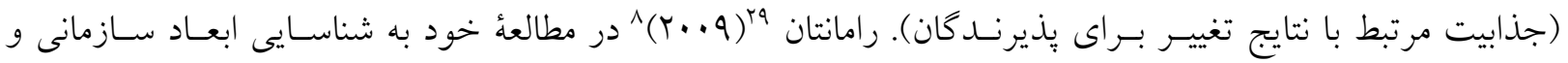
سـاير مؤلفـه هـاى دخيـل در مديريت تغيير اتــبخش برداختـه اسـت. وى جهـار عنصـر كليـدى را در فراينــ تغييـر سازمانى مطرح مى سازد كه عبارت اند از ا. عوامل زمينه اى: شامل عوامل اجتماعى، تجارى، قـانونى، زيرسـاخت فنسى و اجتمـاعى سازمان، سبك رهبرى، كروههاى كارى افراد و ديدگاه افراد است، ؟. شناسايى و برنامه ريزى: شامل توسعهُ رويكرد اجراى تغيير، يعنى هدفگذارى، شناسايى وظايف كليدى و منابع لازم براى اجراى تغيير است گَ. اجرا: در سالهاى اخير در زمينهُ دركير كردن افراد متأثر در برابر تغييسر، در جنبـه هـاى برنامه ريزى و اجراى تغييسر، تحقيقـاتى صـورت كرفتـه اسـت و محققــان از طريق مشاركت دادن افراد، سازمانها را براى غلبه بر مقاومت بـالقوه در برابـر تغييـر و ايجاد نخرش مثبت نسبت به آن توانمند كرده اند، ع. نهادينه كردن: نهادينه سازى تغيير، به تغييراتى در سيستم و سـاختار نيـاز

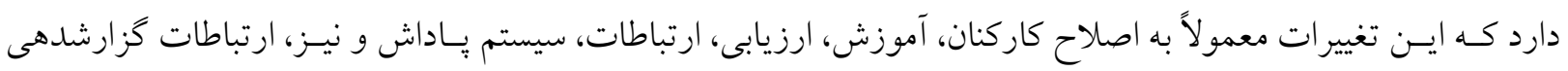
و نقشها مربوط ميشود. عليرغم اهميت مباحث مديريت تغييـر در سازمانها، تحقيقات موجود عمدتاً مفهومى هستند. تغييرات سازمانى عموما به نوعى مرتبط با فناورى اطلاعات مى باشند (ناشى از تغييرات فناورى مى باشد) و مى توانند داراى اشكال مختلفى باشند (N). اخرجهه تغيير در سطح افراد سازمان رخ مىدهد، اما اغلب اداره تغيير در تكى تك افراد براى تيم كارى غيرممكن است. مديريت تغيير با نخاهى به درون سازمان كامها و دستورالعملهايى را در سطح يروزه ارائه مىدهد كه از صدها يا هزاران نفر از افرادى كه تحت تاثير يروزه هستند حمايت كند. مديريت تغيير درون سازمانى در مرحله اول شامل شناسايى گروهها و افرادى است كه به دليل آغاز يروزه تغيير، خود به تغييراتى نياز دارند. در مرحله

\footnotetext{
${ }^{5}$.Lines et all (2015)
}

${ }^{6}$. Rusley et all (2012)

${ }^{7}$.Armenakis et all (2007)

${ }^{8}$.Ramanathan(2009) 
بعد برنامهاى تنظيم مى كند تا از اطلاعرسانى، رهبرى، مربى گرى و آموزش افراد تحت تاثير يروزه تغيير اطمينان حاصل نمايند. تحولات فردى موفق بايد مهمترين نقطه تمركز فعاليتها در مديريت تغيير با نخاهى به درون سازمان باشد. مديريت تغيير با نخاهى به درون سازمان مكملى براى مديريت بروزه شماست (7 (1). مديريت تغيير با نخاه برونسازمانى يكى شايستكى محورى سازمانى است كه تمايز رقابتى و توانايى ساز كارى اثربخش با دنياى دائم در حال تغيير را فراهم مى كند. يكى قابليت مديريت تغيير با نخاه برونسازمانى در نقشها، ساختارها، فرايندها، بروزهها و شايستكى هاى رهبرى سازمان نهادينه شده است.نتيجه نهايى قابليت مديريت تغيير با ديدكاه برونسازمانى اين است كه افراد هرجهه سريعتر و بهتر تغيير را يذيرفته و سازمانها قادرند به سرعت به تغييرات بازار ياسخ داده، راهكارهاى استراتزيك را بذيرفته و سريعاً با فناورىهاى جديد منطبق شوند. بهكونهاى كه كمترين اثر را بر بهرهورى آنها داشته باشد. اين قابليت اتفاقى بدست نيامده و مستلزم يكى رويكرد استراتزيك براى نهادينهسازى مديريت تغيير در سراسر سازمان است (TV). حال با شناخت انوع مقاومت هايى كه در برابر تغيير تكنولوزى صورت مى كيرد، بايستى بر اين مقاومت ها غلبه كرد. جهت غلبه بر مقاومت در برابر تغيير بايستى به جنبه هاى انسانى برنامه تغيير توجه شود. اغلب مديران تمركزشان بر ابعاد تجارى تغيير، دامنه يروزه، فرآيندهايى كه نياز به مهندس مجدد دارند و اجراى راه حل ها مى باشد اما منظور از توجه به بعد انسانى تغيير آنست كه به نحوه واكنش كاركنان نسبت به يديده تغيير يُى ببريم، براى اين منظور مى توان از مدل ADKAR استفاده كرد. به كمك اين مدل مى توان يى به مقاومت كاركنان برده و براى غلبه بر آن برنامه ها و اقدامات اصلاحى مورد نياز را ايجاد كرد. ADKAR مخفف كلمات آكاهى، تمايل، دانش، توانايى و تقويت مى باشد به كمك اين مدل مى تواند ميزان آمادكى كاركنان براى يذيرش تغيير در هر مرحله را تعيين كرده و آنخاه مديران قادر مى شوند برنامه مورد نياز براى ايجاد تغيير را ايجاد كنند (YN).اهميت يذيرش فناورى اطلاعات از طرف استفاده كندكان آن بيش از بيش مشخص شده و بايستى در تدوين راهبرد هاى زير ساخت IT اين مورد در نظر گرفته شود. مدل اوليه يذيرش تكنولوزى، توسط ديويس عرضه شد. دو ادراك اصلى بر مبناى مطالعات قبلى پِيه يذيرش تكنولوزى را تشكيل مى دهد. اين دو ادراك به ترتيب عبارت از سودمندى ادراكى (PU) و سهولت ادراكى ( PEOU) مى باشند (ع)(1). سودمندى ادراكى به عنوان درجه اى كه شخص معتقد است استفاده از يك سيستم خاص عملكرد وى را ارتقاء مى بخشد تعريف شده است. اين تعريف از تعريف سودمندى ييروى مى كند كه قابليت استفاده با مزيت تعريف مى شود. در يكى سازمان، افراد اغلب بوسيله افزايش حقوق، ارتقاء، كارانه وساير بِاداشها تقويت مى شوند. در مقابل سهولت استفاده ادراكى به درجه اى كه يك فرد معتقد است استفاده از سيستم خاص بدون نياز به تلاش زياد ممكن است تعريف شده است. اين تعريف از تعريف سهولت بيروى مى كند كه عبارتست از: بدون تلاش يا سختى زياد. تلاش يكى منبع محدود است كه يك فرد ممكن است به فعاليتهاى مختلف كه مسئول آنهاست، تخصيص دهد (·)(Y)(Y). در سويى ديخر اين مقاومتها مدل يذيرش فناورى يا تم وجود دارد كه هدفش فراهم كردن يك توصيف از يارامترهاى يذيرش كامييوترو فناورى هاى اطلاعاتى است كه عمومى بوده، قابليت توصيف رفتار كاربران از يك دامنه وسيع از تكنولوزيهاى محاسباتى را داشته و كاربران آن 
از انواع مختلف مى باشد. مدل علاوه بر جنبه بيش بينى رويكرد توصيفى هم دارد؛ بنابر اين محققان و مديران مى توانند تشخيص دهند جرا يك سيستم خاص ممكن است مورد يذيرش واقع نشود تا كامهاى اصلاح مناسب را دنبال كنند. يك هدف كليدى تم فراهم كردن مبنايى براى بيخيخى اثر عوامل خارجى بر باورهاى داخلى، طرز تلقى ها و تمايلات است ( آץ)(ب).فناورى اطلاعات توانايى سازمان را براى بقا در محيط رقابتى افزايش مى دهد و مديريت اثربخش؛ آن تأثير

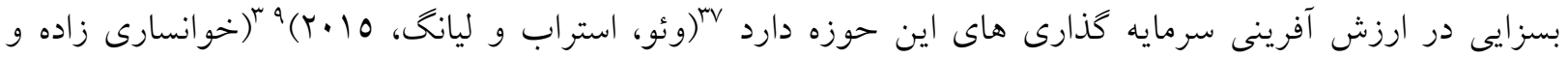
شيرمحمدى، ع9با؛ موسى خانى، مانيان، محمودى و كاركر، 97 (1)?. در مطالعه اى كه شركت هاى تحقيقاتى بين و

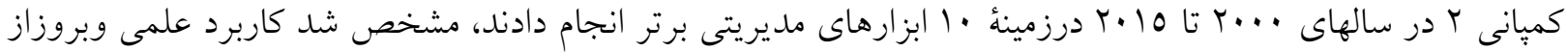

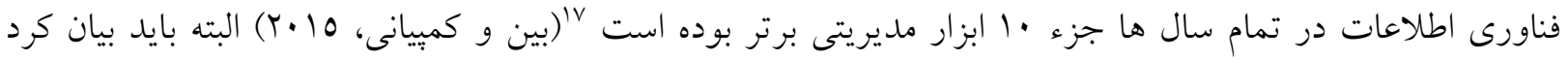

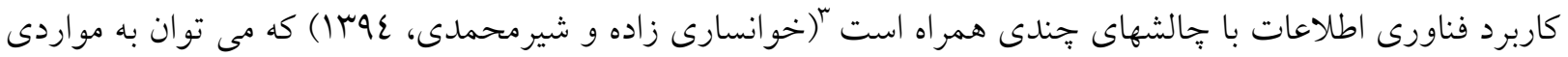
از قبيل تهديدهاى دسترسى، يكيارجگى سامانه ها و منابع، محرمانه بودن اطلاعات، از دست دادن كنترل بر عملكرد و رعايت مقررات اشاره كرد. اين تهديدها مى تواند به از دست رفتن مزاياى رقابتى و حس شهرت سازمان منجر شود و زيان هاى مالى (مانند مخارج انجام دعاوى حقوقى و يرداخت جرايم) را براى سازمانها حتى سازمانهاى ورزشى به دنبال

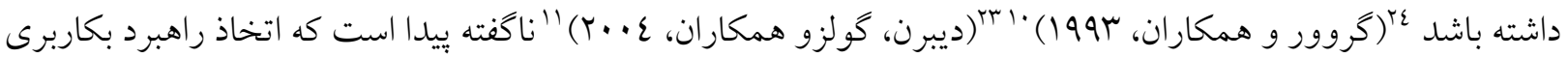
فناورى اطلاعات، تصميم مستقل و مجزايى ازساير مؤلفه هاى سازمانى نيست و تغييراتى را در سازمان به دنبال دارد كه اكر به خوبى مديريت نشوند، زمينه ساز شكست بياده سازى مديريت تغييرو ناورى اطلاعات خو اهند شد. براساس مسئلئ

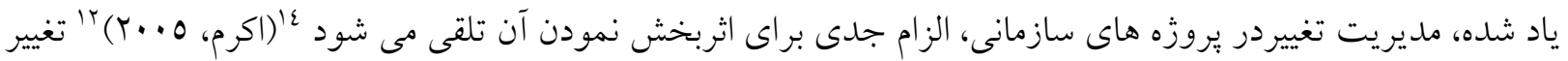
سازمانى جالشى است كه تمام سازمان ها با آن مواجه مى شوند؛ جنبه هاى مختلف سازمان اعم از جنبه هاى راهبردى، مدل كسب وكار، كاركنان و شيوهُ به كاركيرى فناورى را نيز تحت تأثير قرار مى دهد و نيازمند به كاركيرى رويكرد مؤثر

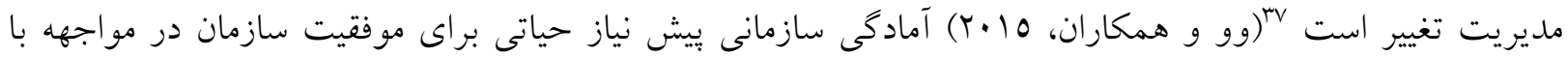
جالش هاى نشات گرفته تغيير است. در موقعيتى كه سازمان آمادگىزيادى براى تغييرداشته باشد، بيادهسازى تغيير

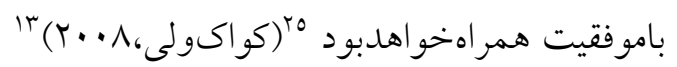

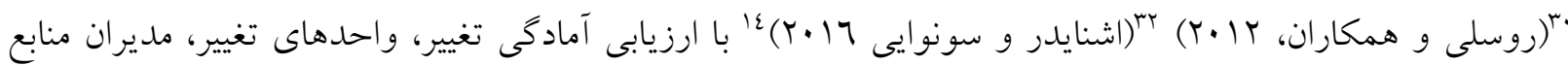
انسانى و مشاوران توسعهُ سازمانى مى تو انند شكاف هاى موجود بين انتظاراتى كه از تلاش هاى تغيير و كاركنان سازمانى دارند راشناسايى كنند. اگر ارزيابى انجام شده دلالت بر فاصلهُ زياد ميان دو سطح ياد شده داشته باشد واقدامى براى از

\footnotetext{
${ }^{9}$.Wu et all (2015)

${ }^{10}$.Grover et all (1993)

${ }^{11}$.Dibbern \& Goles et all (2004)

12 Akram (2005)

${ }^{13}$.Kuwahk \& Lee (2008)

${ }^{14}$.Schneider\&Sunyaev(2016)
} 
بين بردن آن صورت نخيرد، بايد انتظار مقاومت زيادى را داشت كه همكى عامل تهديدكننده موفقيت تغيير هستند (r ا). در واقع بايد گفت، تغييراتى كه يروزه هاى برون سيارى به همراه دارند، نيازمند قابليت هاى جديد افراد و سازمان است

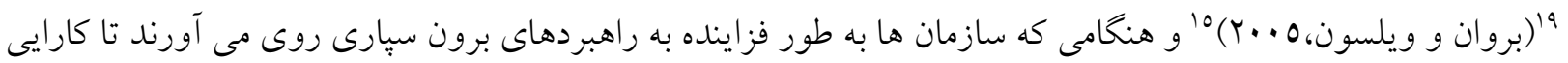
عملياتى و عملكرد كسب وكار را بهبود بخشند، به درك شديد مؤلفه هايى نياز دارند كه به موفقيت مديريت تغيير منجر خواهد شد. ادبيات مديريت تغيير، بر دشوارى و بيجيدگى ماهيت بياده سازى تغيير و درصد بالاى شكست آنها تأكيد مى كند. يكى از دلايل اصلى شكست تلاش هاى تغيير، مقاومت كاركنان سازمان است (TY). استفاده از فناورى اطلاعات و يِياده سازى مديريت تغييردر سازمانهاى ورزشى باعث مى شود تا سازمان سريعتر به محيط خود و ارباب رجوع ياسخ دهد و افراد را قادر مى سازد تا دور از محيط فيزيكى سازمان به انجام وظايف شغلى خود بيردازند. ميزان تحقق اين اهداف از دغدغه هاى مهم تصميم كيرندكان و مديران سازمانهاى ورزشى به حساب مى آيد كه باتوجه به اهميت فراوان مقوله فناورى اطلاعات و ورزش و كمبود تحقيقات صورت يذيرفته دراين زمينه در نهايت ادبيات مرتبط با فناورى اطلاعات بر اقتضايى بودن استفاده آن در سازمانها اشاره دارد؛ بنابراين سازمانها، بخصوص سازمانهاى ورزشى براى ادامه حيات در دنياى ييجيده و متغير نيازمند كسب اطلاعات صحيح و كافى توسط منابع انسانى خود در زمان مناسب هستند كه بدون آن سازمان در درياى عدم اطمينان غوطه ور خواهد بود و تنها جيزى كه ميتواند اين عدم اطمينان را كاهش دهد بياده سازى مديرت تغييروكاربرد درست از فناورى اطلاعات توسط كاركنان آن سازمان است (Y)(T).

\section{روش شناسى بخوهش}

اين تحقيق ازلحاظ روش، توصيفى - همبستخى و ازلحاظ هدف، كاربردى است... جامعدى آمارى در اين يزوهش كارمندان وزارت ورزش و جوانان كشور مىباشد. تعداد حجم جامعه r ا1 نفر و حجم نمونه الب نفر با استفاده ازفرمول كوكران و

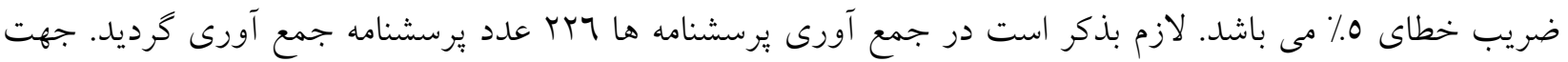
كردآورى دادهها از يرسشنامه به شرح زير استفاده شد.

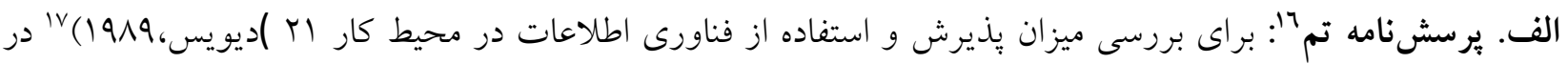
جهار بخش سودمندى ادراكى با 7 سؤال، سهولت ادراكى با 7 سؤ ال، نخرش نسبت بهكاربرد فناورى اطلاعات با ه سؤ ال و تمايل به استفاده از فناورى اطلاعات با ع سؤال و در مجموع اب سؤال بينج ارزشى (ليكرت عدد ا خيلى كم تا عدد ه

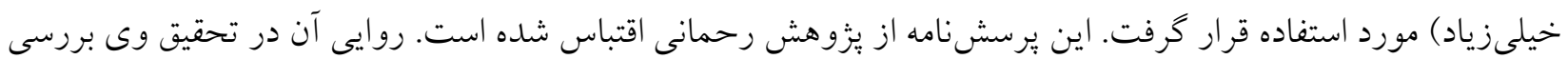

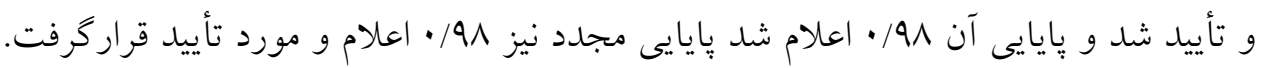

${ }^{15}$.Brown\&Wilson (2005)

${ }^{16}$.Technology Acceptance

17.Davis(1989) 
ب. برسشنامه مديريت تغيير يا ادكار^ا: براى بررسى ميزان و موارد مقاومت كاركنان در برابر تغيير در محيط كار براى سنجش مؤلفهاى آكاهى، تمايل، دانش، توانايى و تقويت (يرسشنامه ينج ارزشى ليكرت) است. يرسشنامه مورد نظر از

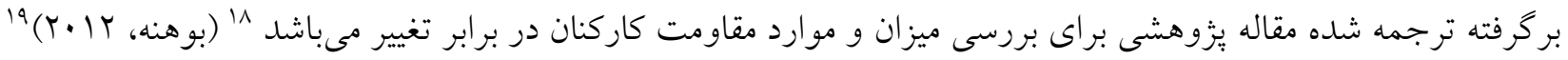
لازم به ذكر است، يرسشنامه فوق استاندارد و بين المللى مىباشد و با تأييد استادان مجدداً روايى لازم را كسب كرده است. يايايى آن نيز در سطح بين المللى آلفاى 97/ • كسبكرده و مورد تأييد قراركرفته است. در اين تحقيق براى تجزيه و تحليل دادهها از آمار توصيفى و استنباطى استفاده شد. به منظور سازمان دادن و خلاصه كردن نمرات خام و توصيف اندازههاى نمونه از آمار توصيفى (ميانخين، درصدها، فراوانى، انحرافمعيار، رسم نمودارها و جداول) استفاده شد. در اين تحقيق از

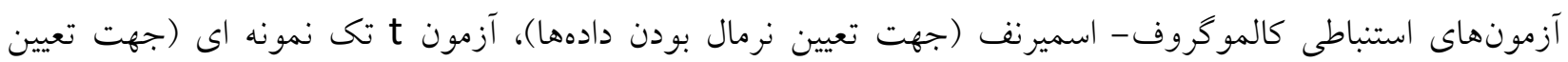

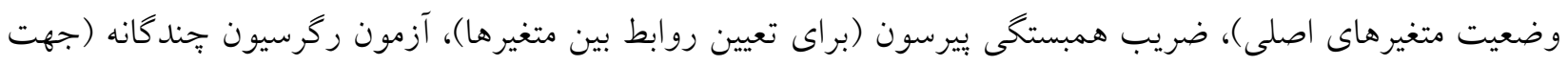
بيش بينى متغيرها) و از مدل سازى معادلات ساختارى (SEM) براى تعيين روابط خطى همزمان بين متغيرها استفاده

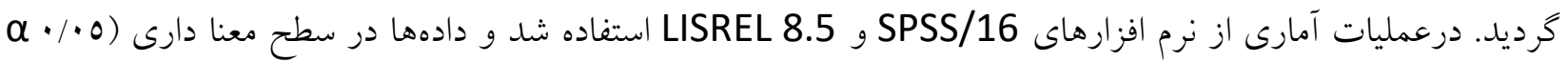
S) تجزيه و تحليل شدند.

\section{يافته هاى يخوهش}

همان كونه كه در جدول (، مشاهده مى شود، نمونه گيرى كاملاً تصادفى در بخشهاى اجرايى مختلف وزارت ورزش و جوانان با سن، سوابق كارى، تحصيلات و جنسيت متفاوت صورت يذيرفته است.

جدول ا. مشخصات فردى

\begin{tabular}{|c|c|c|c|c|c|c|c|}
\hline \multicolumn{2}{|c|}{ آماره مشخصات فردى } & \multirow{2}{*}{$\begin{array}{c}\text { درصد } \\
1 \varepsilon / 10 \\
r r \\
\varepsilon 0 / 0 V \\
I V / r V\end{array}$} & \multirow{2}{*}{$\begin{array}{c}\text { فراوانى } \\
\text { or } \\
\text { or } \\
\text { r.r } \\
\text { ra }\end{array}$} & \multirow{2}{*}{ درصد } & \multirow{2}{*}{$\begin{array}{l}\text { فراوانى } \\
107 \\
\text { V. }\end{array}$} & \multicolumn{2}{|c|}{ آماره مشخصات فردى } \\
\hline سطح تحصيلات & 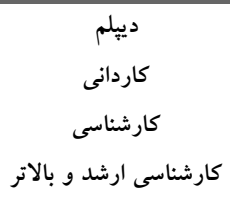 & & & & & زمرد & جنسيت \\
\hline وضعيت آشنايى با رايانه & 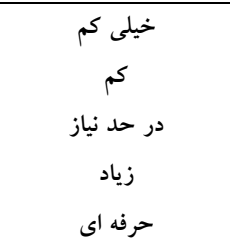 & $\begin{array}{l}1 / \varepsilon . \\
1 N / 01 \\
r \varepsilon / 90 \\
r r / 19 \\
1 \varepsilon / 1 V\end{array}$ & $\begin{array}{l}19 \\
\varepsilon r \\
\text { Vq } \\
\text { OE } \\
\text { rr }\end{array}$ & 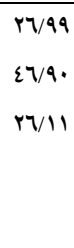 & $\begin{array}{l}71 \\
1.7 \\
09\end{array}$ & 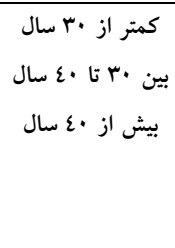 & سن سن \\
\hline وضعيت آشنايى با ايترنت & 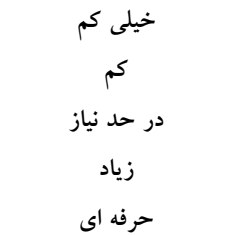 & $\begin{array}{l}\varepsilon / \Lambda T \\
\mid N / 1 \varepsilon \\
r O / \Lambda \varepsilon \\
r / / T \\
19 / \varepsilon V\end{array}$ & $\begin{array}{l}11 \\
\varepsilon 1 \\
11 \\
\varepsilon 9 \\
\varepsilon \varepsilon\end{array}$ & $\begin{array}{l}r Y / O T \\
O Y / Y I \\
\text { YO/YY }\end{array}$ & $\begin{array}{l}01 \\
111 \\
\text { or }\end{array}$ & بين كمتر از 0 سال · بـ ال & سابقه \\
\hline
\end{tabular}

18.ADKAR

${ }^{19}$.Bohene (2012) 
Vتايج تحقيق نشان ميدهد تعداد نمونه هاى تحقيق (107 نفر) يعنى س•/79 درصد از نظر جنسيت مرد هستند و تعداد

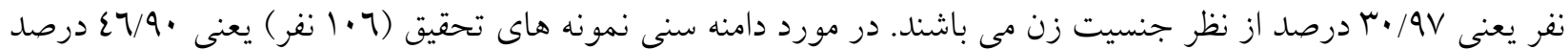

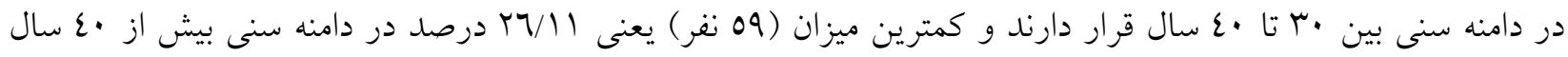

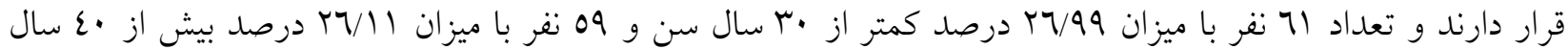
سن را دارا مى باشند.

در جدول شماره r نيز به تعيين وضعيت مديريت تغيير و كاربرد فناورى اطلاعات با استفاده از آزمون تى در وزارت ورزش و جوانان يرداخته شده است.

جدول شماره r. نتايج آزمون t تك نمونهاى براى تعيين وضعيت مديريت تغيير و كاربرد فناورى اطلاعات در وزارت ورزش

\begin{tabular}{|c|c|c|c|c|c|c|}
\hline \multirow{3}{*}{ متغير } & \multicolumn{6}{|c|}{ Test Value $=3$} \\
\hline & \multirow{2}{*}{ آزمون تى } & \multirow{2}{*}{ آزادى } & \multirow{2}{*}{ سطنى } & \multirow{2}{*}{ تفاوت ميانكين } & \multicolumn{2}{|c|}{ فاصله اطمينان از درجه آزادى } \\
\hline & & & & & بإيين ترين & بالا ترين \\
\hline مديريت تغيير & $r / \cdot r \varepsilon$ & TI & •/•हr &.$/ 9700 r$ & $\cdot / \cdot r \cdot \varepsilon$ & $1 / 9 \cdot .7$ \\
\hline كاربرد فناورى & $-1 / \cdot \wedge \varepsilon$ & IVq & $\cdot / \Gamma \wedge$. & $-\cdot / \wedge \cdot 7$ & $-Y / T V I Y$ & •/7091 \\
\hline
\end{tabular}

همانكونه كه در جدول بالا ملاحظه ميشود، با توجه به ميزان t و p p ميتوانيم به اين نتيجه رسيد كه كه مديريت 0 •> تغيير در وزارت ورزش و جوانان از وضعيت تا حدى بالاتر از متوسط برخوردار است؛ به عبارت ديخر مديريت تغيير در وزارات ورزش و جوانان با توجه به معيار تعيين شده (ميانخين نمره ץ از ديدگاه متخصصان براى ميزان متوسط) براى

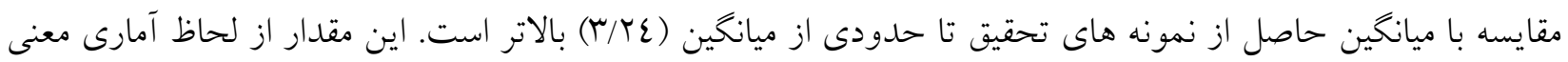

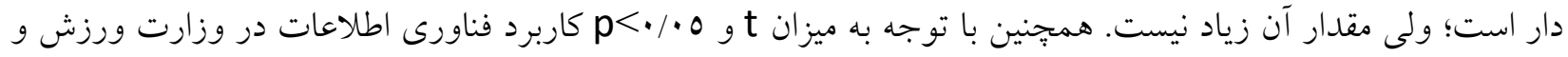
جوانان از وضعيت مطلوبى برخوردار نيست؛ به عبارت ديخر كاربرد فناورى اطلاعات در وزارت ورزش و جوانان با توجه به معيار تعيين شده (ميانخين نمره ץ از ديد كاه متخصصان براى وضعيت متوسط) براى مقايسه با ميانخين حاصل از نمونه هاى تحقيق، از وضعيت مطلوبى برخوردار نيست و تا حدودى كمتر از حد متوسط است.

در جدول شماره ץ به بررسى و تعيين شاخصهاى آمارى از جمله گرايش مركزى، براكندگى و شاخص توزيع جهت خلاصه كردن مجموعه ى داده ها و توضيح جخگونكى توزيع مقاديرمتغيركاربرد فناورى اطلاعات و خرده متغيرهاى آن يرداخته شده است. 


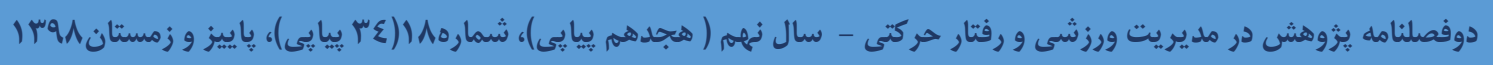

جدول شماره r. شاخص هاى آمارى مرتبط با بررسى متغير (كاربرد فناورى اطلاعات و خرده متغيرهاى آن))

\begin{tabular}{|c|c|c|c|c|c|c|c|c|c|}
\hline \multicolumn{3}{|c|}{ شاخصهاى توزيع } & \multicolumn{3}{|c|}{ شاخص هاى بر اكندىى } & \multicolumn{4}{|c|}{ شاخص هاى گر ايش مركزى } \\
\hline ضريد & ضريب & خعاى & انحر اف معيار & واريانس & تغييرات & ميانكين & 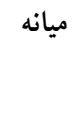 & 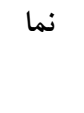 & عنوان متغير \\
\hline ./ह94 & $\cdot / r \cdot 9$ & $\cdot / V \varepsilon r$ & $1 / r Y 7$ & 1/VON & 0 & $r / \cdot 1$ & $r$ & $r$ & كاربرد فناورى \\
\hline$\cdot / 0 \varepsilon 1$ & $\cdot 1011$ & $\cdot / Y 11$ & $1 / Y 10$ & $1 / \varepsilon \vee 7$ & $\varepsilon / v_{0}$ & $r / 7 r$ & r/or & $r / r r$ & سودمندى درك شده \\
\hline$\cdot / r \varepsilon 1$ & $-\cdot / \cdot \varepsilon V$ &.$/ 199$ & $1 / \cdot r \varepsilon$ & $1 / \cdot 79$ & 0 & $r / v\urcorner$ & $r / r \varepsilon$ & $r / 70$ & سهولت درك شده \\
\hline.$/ \cdot 7 V$ & 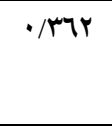 & ./rYq & $1 / \varepsilon 91$ & $r / Y \varepsilon \varepsilon$ & $\varepsilon / 0$ & $r / 11$ & $r$ & $r$ & نكرش نسبت به \\
\hline$\cdot / / Y \Lambda$ & $\cdot / \varepsilon q \vee$ & - /Yrq & $1 / \varepsilon 91$ & $T / Y \varepsilon \varepsilon$ & 0 & $r / A r$ & $r / \varepsilon 0$ & $r / 19$ & تمايل به استفاده \\
\hline
\end{tabular}

با توجه به شاخصهاى آمارى بدست آمده و با تأكيد بر اينكه تفاوت اندكى بين نما، ميانه و ميانخين وجود دارد و از آنجايى كه ميزان ضريب كجى و ضريب كشيدكى كمتر از رقم V/ • است، توزيع فوق، مفروضه نرمال بودن را داراست و مى توان از ميانخين بعنوان معرف شاخص گر ايش مركزى استفاده و از مدلهاى آمار بار امتريكى استفاده كرد.

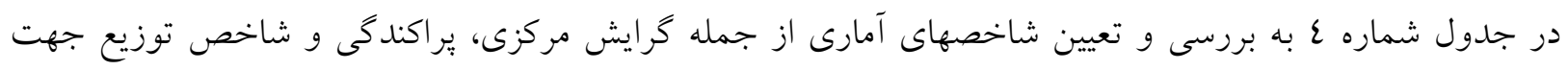
خلاصه كردن مجموعه ى داده ها و توضيح جخونكى توزيع مقاديرمتغيرمديريت تغييرو خرده متغيرهاى آن يرداخته شده

جدول شماره ع. شاخصهاى آمارى مرتبط با بررسى متغير (مديريت تغيير و خرده متغيرهاى آن)

\begin{tabular}{|c|c|c|c|c|c|c|c|c|c|}
\hline \multicolumn{3}{|c|}{ شاخص هاى توزيع } & \multicolumn{3}{|c|}{ شاخص هاى براكندىى } & \multicolumn{4}{|c|}{ شاخص هى گرايش مركزى } \\
\hline ضريب & ضريب & 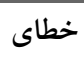 & انحراف & واريانس & 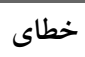 & خطاى & 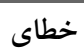 & نما & عنوان متغير \\
\hline كشيدگى & كجى & 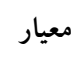 & 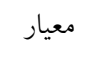 & & 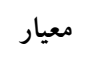 & 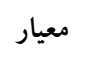 & 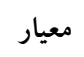 & & \\
\hline$\cdot \pi T \varepsilon$ & $\cdot / \cdot \sum \wedge$ & $\cdot / \varepsilon \vee \varepsilon$ & T/YTq & $\varepsilon / 971$ & $\varepsilon$ & $r / r \varepsilon$ & $r$ & r/Tr & مديريت تغيير \\
\hline$\cdot \pi r \varepsilon$ & $\cdot \pi / r$ & $\cdot /$. TYI & $r / 07 \varepsilon$ & T/ov & 0 & $r / v \varepsilon$ & $r / \varepsilon \varepsilon$ & $r / 0$. & آكاهى از نياز براى تغيير \\
\hline ( & . & אוד & $1 / 0 \varepsilon r$ & $r / \mu \Lambda$. & $\varepsilon / N_{0}$ & $r / 10$ & $r / \varepsilon$ & $r$ & مطلوبيت اجراى تغيير \\
\hline$\cdot / T \wedge T$ & $\cdot \pi \varepsilon r$ &.$/ 1 \pi \mu$ & 1/1rr & $1 / r 71$ & 0 & $r / 17$ & $r$ & $r / 11$ & دانش دربارهٔ جكونگى تغيير \\
\hline$\cdot \pi \varepsilon q$ & $\cdot \pi \mu \varepsilon$ & . & $r / r \varepsilon 0$ & $7 / 70 \varepsilon$ & 0 & $r / \cdot \Lambda$ & $r$ & $r$ & توانايى اجراى مهارت ها و \\
\hline$-\cdot / \varepsilon r T$ & $\cdot \pi r 1$ & r & T/YNO & O/TYI & $\varepsilon / 0$ & $r / 1$ & $r$ & $r$ & تقويت حفظ تغيير \\
\hline
\end{tabular}




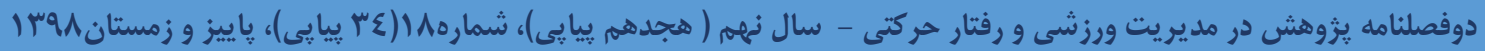

با توجه به يافته هاو با تأكيد بر اينكه تفاوت اندكى بين نما، ميانه و ميانكين وجود دارد و از آنجائيكه ميزان ضريب كجى و ضريب كشيدگى كمتر از رقم V/• است، توزيع فوق، مفروضه نرمال بودن را داراست و مىتوان از ميانخين بهعنوان معرف شاخص كرايش مركزى و از مدلهاى آمار يارامتريك استفاده كرد.

در جدول شماره ه از ضريب همبستخى بيرسون براى تعيين ارتباط بين خرده متغيرهاى فناورى اطلاعات و خرده متغيرهاى مديريت تغيير استفاده شده است.

جدول شماره 0. نتايج ضريب همبستى بيرسون براى تعيين ارتباط (مولفه هاى فناورى اطلات) با (مؤلفه هاى مديريت تغيير)"

\begin{tabular}{|c|c|c|c|c|c|c|}
\hline تقويت حفظ & توانايى براى اجراى مهارت & جانش درباره & اجراى تغيير & آكاهى از نياز & شاخص هاى & متغير \\
\hline$\cdot / 77^{* * *}$ & $\cdot / Y^{*}$ & $\cdot / 0 \varepsilon^{* * *}$ & $\cdot / 7 Y^{* * *}$ & 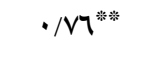 & $\mathbf{R}$ & \multirow{2}{*}{ سودمندى ادراك } \\
\hline 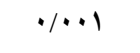 & .1010 & $\bullet / \cdot 1$ & 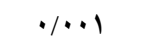 & 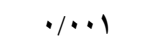 & Sig & \\
\hline$\cdot 10 \cdot{ }^{* * * 3}$ & $\cdot / \Gamma q^{* * * \sigma^{*}}$ & $\cdot / V 9^{* * * *}$ & $\cdot / r I^{*}$ & $\cdot / 0 r^{* * *}$ & $\mathbf{R}$ & \multirow[b]{2}{*}{ سهولت ادراك } \\
\hline$\cdot \cdots 1$ & $\bullet / \cdots 1$ & $\bullet / \cdot 1$ & 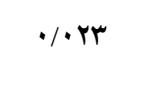 & $\bullet / \cdot 1$ & Sig & \\
\hline$\cdot / \varepsilon \varepsilon^{* * * *}$ & $\cdot / 09^{* * *}$ & $\cdot / 71^{\text {米* }}$ & $-\cdot / 1 V^{*}$ & $-\cdot / r Y^{*}$ & $\mathbf{R}$ & \multirow[b]{2}{*}{ كاربرد ن نكبت به } \\
\hline$\bullet \cdot \cdot 1$ & $\cdot \cdots 1$ & $\cdot / \cdot 1$ &.$/ r r$ & $\cdot|\cdot r|$ & Sig & \\
\hline$\cdot / r Y^{*}$ & $\cdot-/ 79^{* * *}$ & • &.$/ 10$ & $\cdot|乏|^{* * * *}$ & $\mathbf{R}$ & \multirow{2}{*}{ تمايل به استفاده } \\
\hline •/.rY & $* \cdots 1$ & $* \cdots 1$ & $\cdot / \cdot V Y$ & 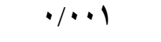 & Sig & \\
\hline
\end{tabular}

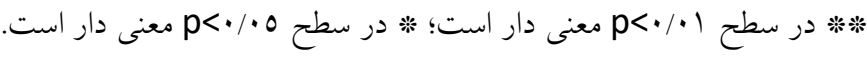

با توجه به يافته هاى جدول شماره 0، بين سودمندى ادراك شده و مؤلفه هاى مديريت تغيير در وزارت ورزش و جوانان رابطه معنى دارى وجود دارد (0 •/p). بين سهولت ادراك شده و مؤلفه هاى مديريت تغيير در وزارت ورزش و جوانان رابطه معنى دارى وجود دارد (0•/p) (p). بين نخرش نسبت به كاربرد و مؤلفه هاى مديريت تغيير در وزارت ورزش و جوانان رابطه معنى دارى وجود دارد (0•/p). بين تمايل به استفاده و مؤلفه هاى مديريت تغيير در وزارت ورزش و

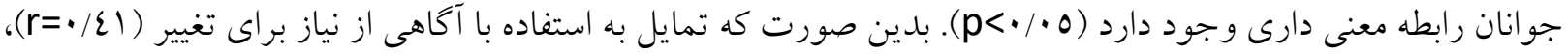

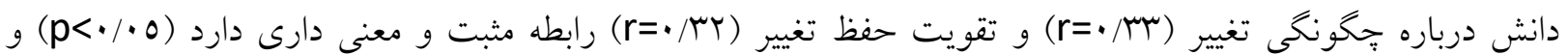
همجنين تمايل به استفاده با توانايى براى اجراى مهارت ها و رفتار جديد (79/ •r=-r) داراى رابطه منفى و معنى دار است

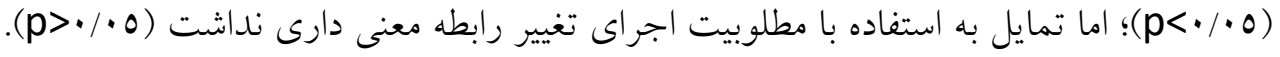


تحليل مسير •rمى تواند روابط علّى بين متغيرها را تعيين كند و با بيان رسمى يكى مدل از طريق كزارههاى آمارى بدنبال اين است تا پارامترهايى را در حيطهُ رابطهُ بين سازهها برآورد سازد. اينكونه برآوردها، معادلات رياضى بوده و مىتواند معادلات ساختارى را براى يك سازه ايجاد كند. در روند تحليل مسير، همواره براساس اندازهيرىهاى روانشناختى، با دو متغير سروكار داشته كه اينخونه متغيرها را بعنوان متغيرهاى آشكار و اندازهكيرى شده و متغيرهاى ينهان، يا مكنون و يا استنباط شده تعريف مى كنند. در اين تحقيق يس از تعيين روابط بين متغيرهاى تحقيق؛ متغيرهاى اصلى در LISREL 8.8بررسى شدند و مفروضات آمار يارامتريك با تأكيد بر نرمال بودن توزيع جندمتغيرى بدست آمد. بِ إز اينكه مدل

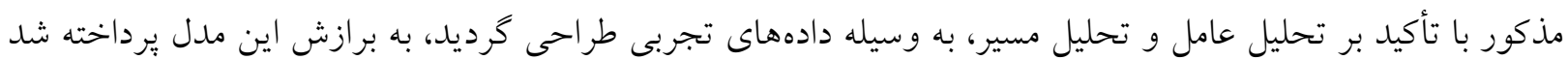
و شاخصهاى مرتبط با نيكويى برازش و خطاهاى اندازهگيرى بدست آمد كه در اين زمينه، از سه شاخص متفاوت استفاده گرديد. با تأكيد بر تمامى اين سه شاخص، مشخص كرديد كه مدل مزبور، از برازش برخوردار است و كارايى بالايى در توصيف روابط بين متغيرها داراست.

در جدول شماره 7 شاخص هاى برازش مدل تحقيق از جمله شاخص برازش مطلق كه از ا ساسى ترين و اصلى ترين معيارها براى صحت و سقم برازش داده ها بر اساس مدل يا فرضيات ييشنهاد شده مى باشند كه بر مبناى تفاوت ميان واريانس ها و كوواريانس هاى دو مدل مشاهده شده و تدوين شده اندازه گيرى مى شود؛ هرجه تعداد يارامترهاى مدل بيشتر باشد، شاخص هاى برازش مطلق بهبود خواهند يافت و به سمت مدل اشباع شده (برازش كامل) نزديكتر مى شود. شاخص تطبيقى كامى در جهت تكميل شاخص برازش مطلق مى باشد و در شاخص مقتصد مهمترين نقطه ضعف شاخص برازش مطلق يعنى بهبود مقدار شاخصهاى برازش با افزايش بار امتر به مدل جبران مى شود.

جدول شماره 7 شاخص هاى برازش مدل تحقيق

\begin{tabular}{|c|c|c|c|c|}
\hline تفسير & ملاكى & ميزان & شاخص برازش & \\
\hline 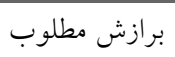 & - & 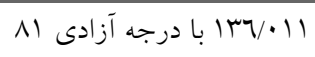 & $x^{2}$ & \multirow[t]{3}{*}{ مطلق } \\
\hline برازش مطلوب & 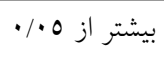 & $\cdot / \cdot \Lambda \Lambda T$ & $\mathrm{p}$ value & \\
\hline 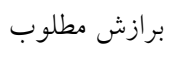 & 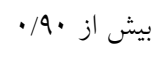 & $\cdot / 99$ & شاخص نيكويى برازش (GFI) & \\
\hline 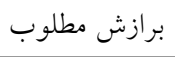 & 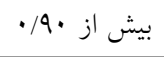 & $\cdot / 97$ & شاخص توكر - لويس (TLI) & \multirow[t]{3}{*}{ تطبيقى } \\
\hline 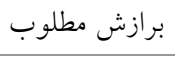 & 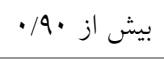 & $\cdot / 91$ & شاخص برازش بنتلر - بونت (BBI) & \\
\hline 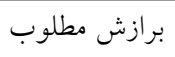 & 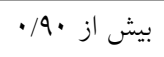 & $\cdot / 91$ & شاخص برازش تطبيقى (CFI) & \\
\hline 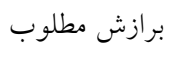 & 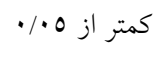 & $\cdot / \cdots \cdot v 1$ & ريشه ميانخين مربعات خطاى بر آورد (RMSEA) & \multirow[t]{2}{*}{ 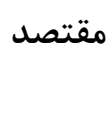 } \\
\hline 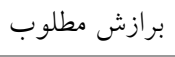 & 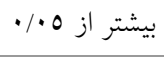 &.$/ 79$ & شاخص برازش مقتصد هنجار شده (PNFI) & \\
\hline
\end{tabular}

20. Path analysis 
شكل شماره ا: مدل نهايى تحقيق

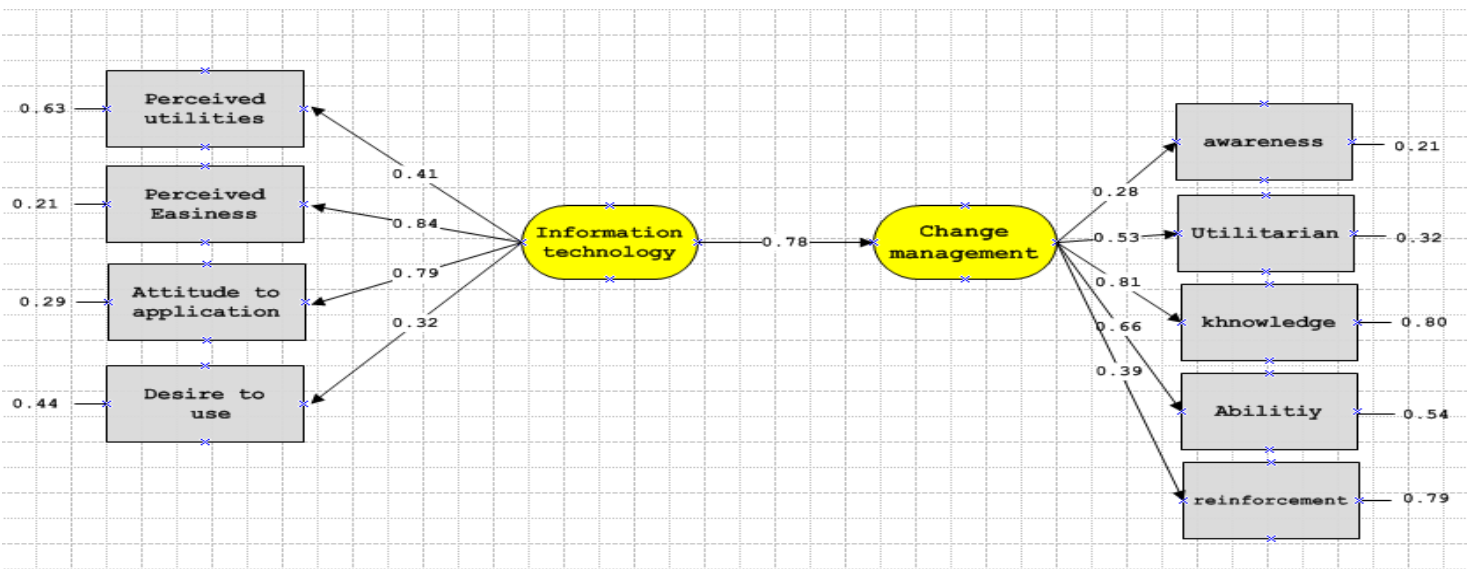

Chi-square $=136.011, d f=81, P$-value $=0.0882$, RMSEA $=0.00071$

\section{نمودار تحليل مسير و ضرايب مسير در مدل نهايى تحقيق}

در زير نمودار مربوط به نمرات t در تحليل مسير مشاهده مى شود. از آنجايى كه تمامى نمرات t بزركتر از 1/97 +و و 1/97 - است، معنى دارى آمارى ضرايب مسير در مدل تحليل مسير تأييد مى شود. شكل شماره Y: نمودار تحليل مسير و ضرايب مسير در مدل نهايى تحقيق

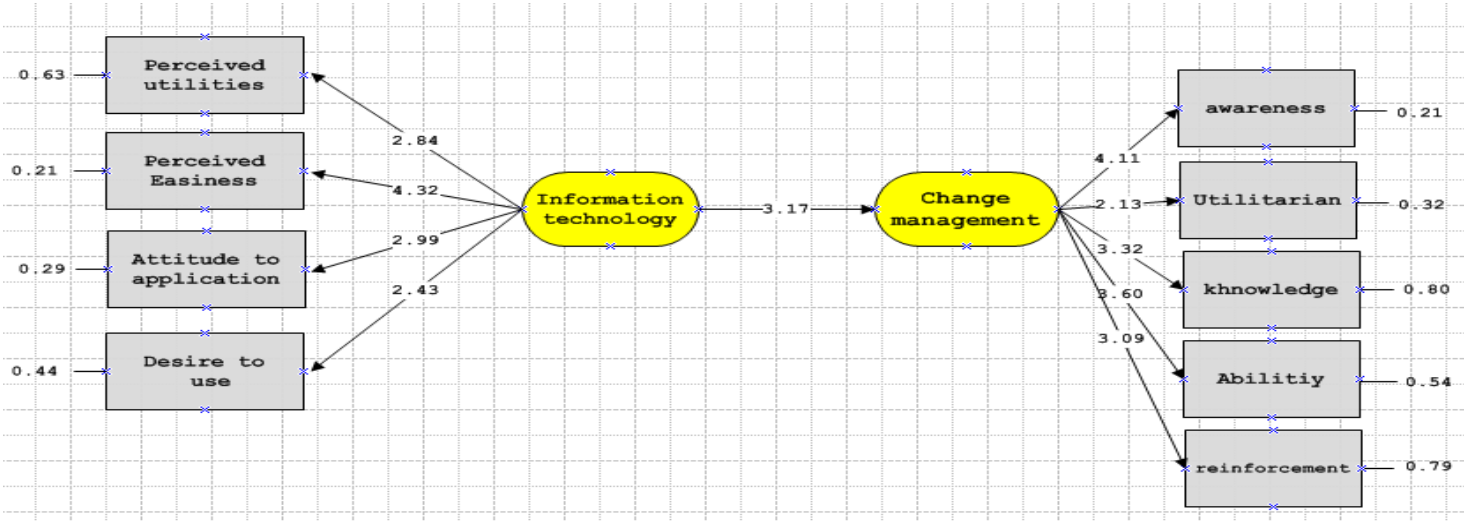

Chi-square $=136.011, d f=81, P$-value $=0.0882$, RMSEA $=0.00071$

\section{مقادير t در ضرايب مسير مدل نهايى تحقيق}

براى آزمون اينكه مدل يزووهش از برازش مناسبى برخوردار است؛ از شاخص هاى مداى برازش مدل استفاده شد. براساس زير

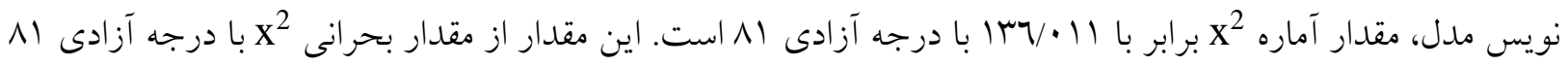

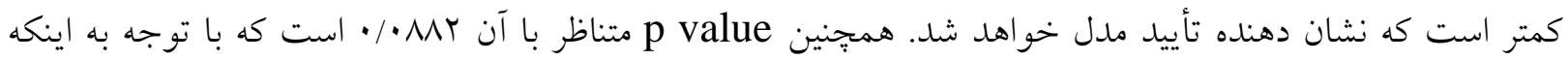
بيشتر از 0 • • است؛ قابل قبول بوده و تأييد مىشود. شاخص نيكويى برازش (G9I) •99 • است كه نشان دهنده قابل 


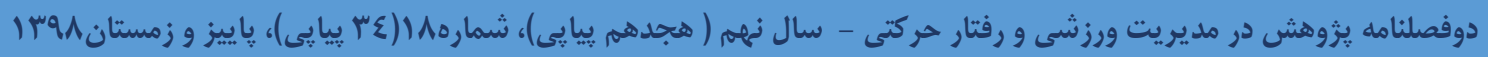

قبول بودن اين ميزان براى برازش مطلوب مدل است. مقدار ريشه ميانخين مربعات خطاى برآورد (RMSEA) كه

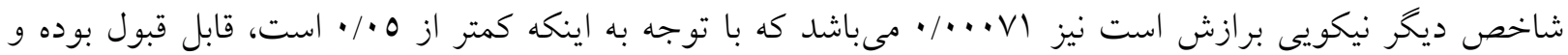

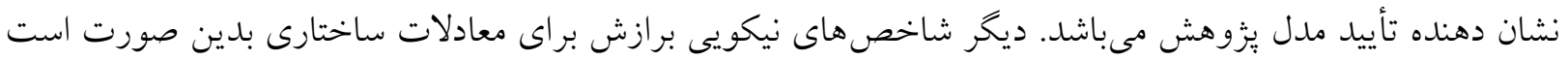
كه مقدار شاخص توكر - لويس (TLI)

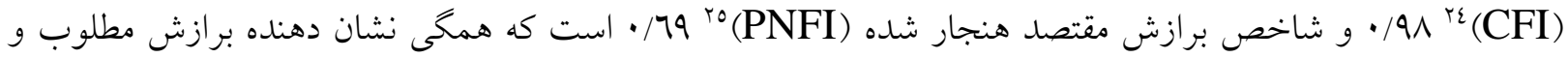

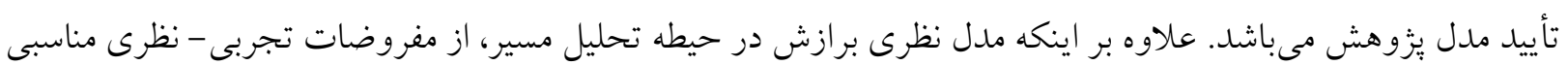
برخوردار بوده، مىتوان اينكونه تفسير كرد كه كاربرد فناورى اطلاعات با ضريب مسير (pc=•/VN) بر مديريت تغيير اثر مستقيم است. در اثر كذارى كاربرد فناورى اطلاعات بر مديريت دانش به ترتيب سهولت درك شده با بار عاملى ع^/•، نغرش نسبت به كاربرد با بار عاملى V9/•، سودمندى ادارك شده با بار عاملى |ع/• و در نهايت تمايل به استفاده با بار

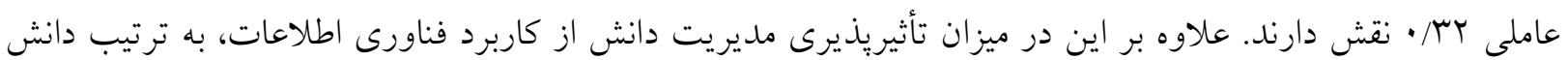

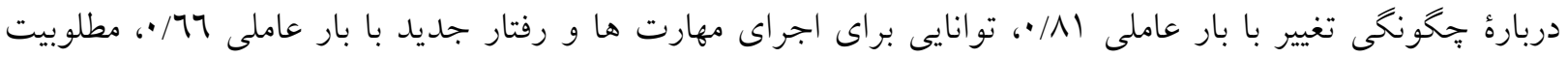

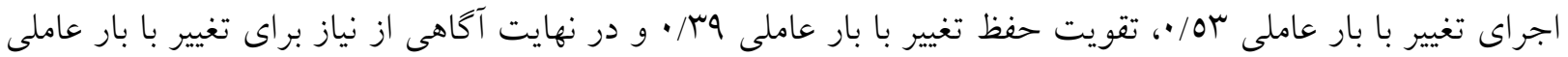

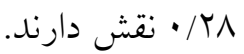

\section{بحث و نتيجه تيرى}

علاوه بر اينكه مدل نظرى برازش در حيطه تحليل مسير، از مفروضات تجربى - نظرى مناسبى برخوردار بوده، مىتوان

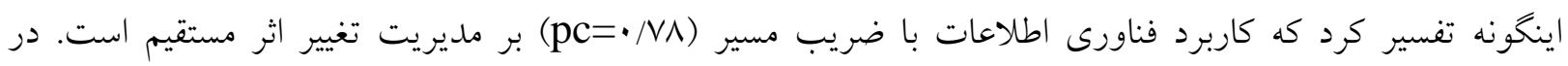

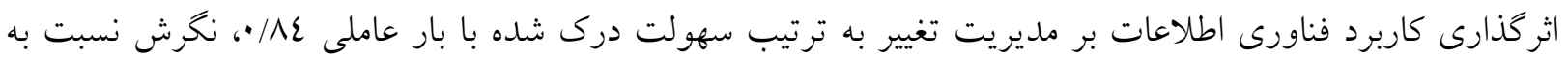

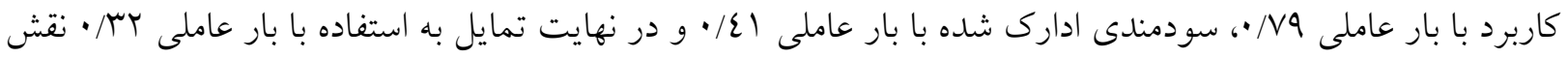

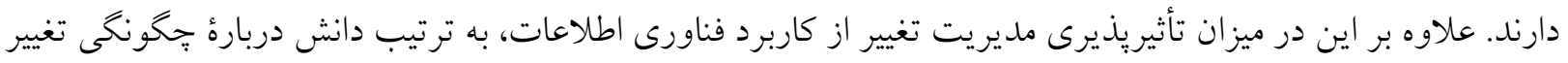
با بار عاملى ای/•، توانايى براى اجراى مهارت ها و رفتار جديد با بار عاملى 77/، مطلوبيت اجراى تغيير با بار عاملى

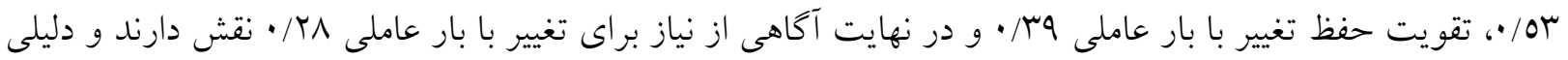
بر قابل بيش بين بودن مديريت تغيير از طريق مولفه هاى كاربرد فناورى اطلاعات مى باشد. از سوى ديخركاربرد فناورى اطلاعات بر مديريت تغيير اثر كذار است؛ يعنى هرجه قدر كاربرد فناورى اطلاعات بيشتر باشد، ميزان تأثيريذيرى مديريت تغيير از آن بيشتر است. حال كه هم كاربرد فناورى اطلاعات و مديريت تغيير داراى مؤلفه هايى هستند؛ براساس ميزان بار عاملى (ميزان تعيين كنندگى اين نقش اثر كذارى) اهميت آنها مشخص مى شود. دراثر گذارى كاربرد فناورى اطلاعات، بيشترين نقش را سهولت ادراكى دارديعنى ميزان بار عاملى آن بيشتر از ساير مؤلفه هاست، بنابر اين نتيجه مى توان اينخونه

\footnotetext{
21. Root Mean Squared Error of Approximation

22. Tucker- Lewis Index

23. Bentler- Bonett Index

24. Comparative Fit Index

25. Parsimonious Normed Fit Index
} 
استنباط كرد كه هر جه دركاربرد فناورى اطلاعات به مسئله سهولت استفاده از فناورى ورايانه توجه شود، مى توان اميدوار بود كه مديريت تغيير بهتر صورت كيرد. بعد از سهولت ادراكى، مؤلفه بعدى كه بيشترين ميزان بار عاملى را دارد نخرش كاء نسبت به كاربرد ميباشد واين بدين معنى است مسئولان وزارت ورزش و جوانان بايد اين امر را به كاربران القا كنند كه تغيير نخرش نسبت بكاربرد فناورى اطلاعات و داشتن نخرشى مثبت ميتواند يك روند مثبت و سازنده مديريت تغيير در سازمان اميدوار بود. بِ از نحرش نسبت به كاربرد، مؤلفه بعدى كه بيشترين ميزان بار عاملى را دارد، سودمندى ادراكى كي

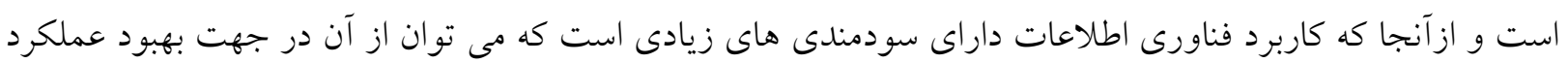
وزارت ورزش و جوانان بهره برد. در مرحله بعدى تمايل به استفاده قرار دارد كه بيانگر اين موضوع است كه هرجه. كاربران در وزارت ورزش و جوانان تمايل بيشترى به استفاده از فناورى اطلاعات داشته باشند كمك بيشترى در روند يياده سازى آسان و بى دغدغه مديريت تغيير در سازمان خود داشته باشند. در تقسيم بندى كلى اين مولفه ها در دسته

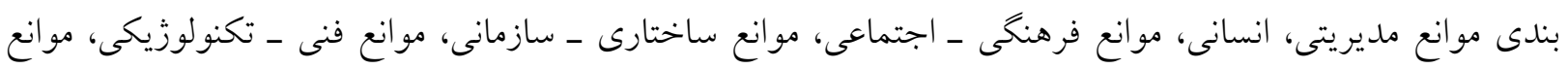
فردى و محيطى قرا مى گيرند. اما در جهت ديخر، مديريت تغيير قرار دارد. در مديريت تغيير كه متغيرى است كه متأثر از متغير ديخر (كاربرد فناورى اطلاعات) است، ميزان نقش كذارى مهم است. در ميان مؤلفه هاى مديريت تغيير بيشترين نقش با مؤلفه دانش درباره جֶ) نكى تغيير است؛ زيرا بيشترين بار عاملى داردو اينخونه استنباط ميخردد كه براى ايجاد يك مديريت تغيير مطلوب در وزارت ورزش و جوانان بايد دانش كافى در مورد تغيير وجود داشته باشد. در واقع دانشى كه متأثر از كاربرد فناورى اطلاعات است. در مرحله بعدى تقويت حفظ تغيير قراردارد داردو اينخونه استنباط ميخردد كه براى ايجاد يكى مديريت تغيير مطلوب در وزارت ورزش و جوانان بايد تغيير بوجود امده را يشتيبانى و تقويت نمود و ميتوان اين موضوع را با

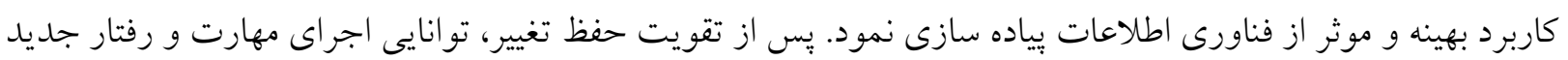
در تغيير در مرحله بعدى قرار ميخردد و اين نشاندهنده آنست كه بالا بردن كيفيت و كميت تواناييها براى اجراى مهارت و رفتار جديد در محيط تغيير تنها با كاربرد موثر و سازنده فناورى اطلاعات امكانيذير ميباشد. در مرحله بعدى مطلوبيت حفظ تغيير قرار دارد واين اطلاع از اين موضوع است كه بدانيم تغيير بوجود آمده در جهت رشد وشكوفايى سازمان است و اين موضوع كه اين تغيير مطلوب و سازنده خواهد بود و نتايج مثتى براى سازمان خواهد داشت و اين مطلوبيت رخ نخواهد داد مخر با استفاده و كاربرد مناسب و متناسب فناورى اطلاعات در سازمان؛ كان و آخرين مورد آكاهى از نياز براى تغيير است كه كمترين بار عاملى را بدست آورده و اين مبين اين موضوع است كه أكاهى از اين موضوع كه سازمان در شرايطى قراردارد كه براى رشد و شكوفايى و سازندگى و حتى در موارد ضرورى رقابت با ساير سازمانها نياز به تغيير دارد در تقسيم بندى كلى اين مولفه ها در دسته بندى موانع فردى و محيطى و انسانى قرار مى كيرند.

يزووهشهاى زيادى به بررسى نقش واهميت وتاثير مولفه هاى كاربرد فناورى اطلاعات در مديريت تغيير وانجام وظايف

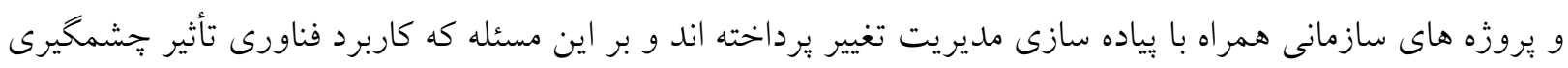
بر بهبود عملكرد مديريت تغييردر سازمان دارد تأكيد داشته و اذعان ميدارند استفاده از رايانه و فناورى اطلاعات موجب 
نظام مند شدن داده هاى سازمان ميشود در واقعااگر تلاش مناسبى براى بكارگيرى صحيح فناورىاطلاعات ومحور

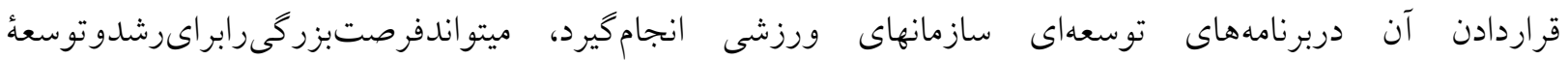
ورزش كشوروهمجنين كاهش مقاومت دربرابرمديريت تغيير توسط منابع انسانى فراهم كند در واقع يافته هاى تحقيقات همخوان بر بالا بردن سطح سواد فناورى كاربران كه اين موضوع خود به بالا رفتن دانش و آكاهى از تغيير مورد نياز

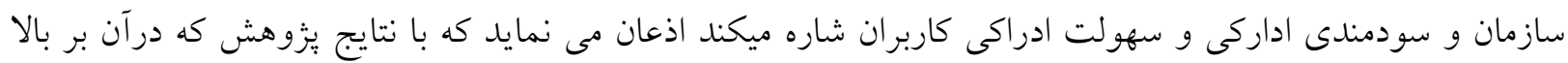
بردن آكاهى از نياز براى تغييرو همجنين نقش مهم دو مولفه سودمندى اداركى و سهولت ادراكى در كاربران براى تسهيل

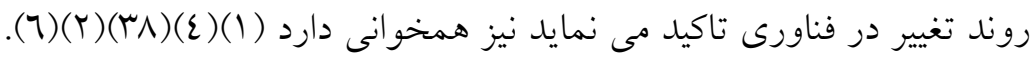

يكى از مهمترين كامها براى بيشبرد ييشرفت و ياده سازى موفق مديريت تغيير درسازمانهاى ورزشى شناسايى مولفه هاى كاربرد فناورى اطلاعات و تاثير گذارى آنها بر روى مديريت تغيير مى باشد، موانع گوناگونى بر سر راه اشاعهُ فناورى اطلاعات وجود دارند كه موجب كندى روند رشد آن در بياده سازى مديريت تغيير در سازمان ميشوند از جملهُ اين مولفه ها كه بيشترين تاثير را دارا مى باشند ميتوان به سهولت ادراكى و نخرش نسبت به كاربرد اشاره كرد كه در هردو در رده بندى مولفه هاى كاربرد فناورى اطلاعات كنجيده و با نتايج تحقيق كه يه اين موارد اشاره نموده و علاوه برآن بر بالا

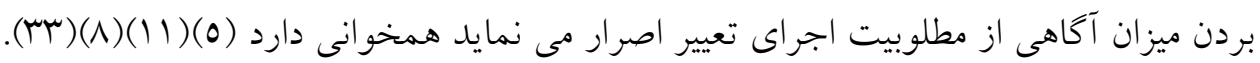

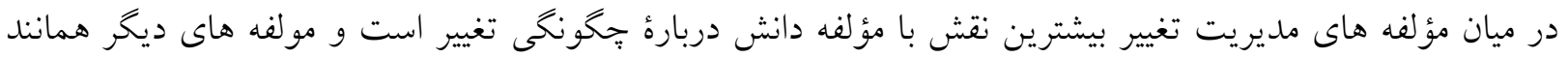
تقويت حفظ تغيير، توانايى اجراى مهارت و رفتار جديد در تغيير و مطلوبيت حفظ تغيير در سازمانهاى ورزشى را شايد بتوان در كمبود منابع انسانى متخصص و عدم به روزرسانى وظايف و وضعيت نه جندان مطلوب آشنايى كاركنان اين سازمان با فناورى اطلاعات و مديريت تغيير، نبود برنامه هاى عملياتى و راهبردى فناورى اطلاعات در سازمانهاى ورزشى و نبود ساختار سازمانى مناسب در كلية سطوح مديريتى ر سازمانها دانست كه با نتايج تحقيق در خصوص وضعيت نه

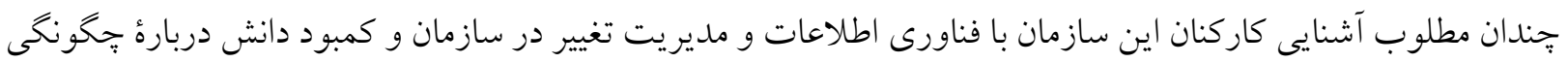

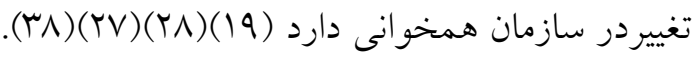
در برخى از تحقيقات محققين از جمله موارد متاثر از فناورى اطلاعات به مواردى از جمله موارد فنى و تكنولوزيكى و همجنين عدم سرمايه گذارى مناسب، قوانين و مقررات نامناسب و محدوديت تقاضا براى فناورى اطلاعات و كاربردهاى نابهجاى فناورى اطلاعات در سازمان و وضعيت نامناسب اقتصادى سازمانها نام برده اند كه بطور كل يا نتايج تحقيق

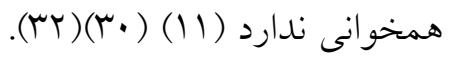
آموزش منابع انسانى خصوصاً در وزارت ورزش و جوانان جمهورى اسلامى مىتواند به تعامليذيرى، امنيت، انعطافيذيرى، مقياسيذيرى سازمان كمك مىنمايد. در اختيار داشتن نيروى انسانى مستعد و با تجربه و تحصيل كرده در زمينه استفاده از فناورى اطلاعات براى اجراى طرح جامع سازمانى در اغلب سازمانها خصوصاً سازمانهاى ورزشى ئشى و توجه جهانى به ضرورت امر و كسب رتبه قابل قبول در سطح جهان براى كشورها از نظر روند استفاده كارا و اثربخش از انواع فناورى اطلاعات و استقبال خوب مديران از بهكاركيرى و بيادهسازى فناورى اطلاعات سازمانها از موارد قابل 


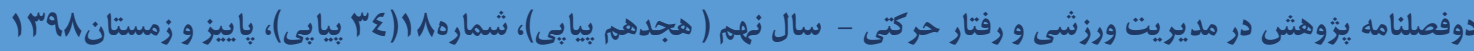

تأملى است كه بايد مسؤولان وزارت ورزش و جوانان آنها را مورد توجه قرار دهند. وقتى كه استفاده از يك فناورى جديد خصو صا فناورى اطلاعات توسط مديران بخش ورزشى با توجه به ارزشهاى موجود و نيازهاى حرفهاى حمايت كردد، منابع انسانى آن سازمان نه تنها اعتماد به نفس بيشترى در استفاده از فناورى اطلاعات را خواهند داشت، بلكه درجه بالاترى از ادراك و مزاياى سيستم را نشان مى دهند و به احتمال زياد از اين فناورى استفاده بهينهترى خواهند كرد، لذا بيشنهادهايى در ادامه ارايه شده است:

مديران ارشد و دست اندركاران ورزش و به جنبههاى فردى افراد مشغول در سازمان توجه بيشترى كرده، آموزشهاى لازم قبل بياده سازى سيستمهاى اطلاعاتى را به خوبى در اختيار افراد قرار دهند و آنها را با مزايا و قابليتهاى فناورىهاى جديد آشنا كنند متاسفانه عدم توجه به جنبه هاى فردى منابع سازمانى و عدم آموزش كاربران از مواردى است كه ناديده كرفته شده است.

همجنين، آنها را در تصميماتى كه براى استفاده از اين گونه تكنولوزىها گرفته مىشود دخيل كنند تا انجام امور در زمان كمترى يا تسهيل روند كارى صورت يذيرد اين مورد در كاهش ميزان مفاومت كاربران براى استفاده از فناورى هاى تازه در بياده سازى مديريت تغيير از موانعى است كه توجه به آن كاملا ضرورى بنظر مى رسد.

\section{منابع}

1 - اخوان صراف، احمدرضا (T . .Y). مديريت تغيير براى اجراى فناورى اطلاعات. ماهنامه تدبيرسال هفدهم شماره

$$
.1-1 \cdot 1 \mathrm{r}
$$

Y - اشرف گنجويى و همكاران (1/49). توصيف نخرش مديران ستادى ادارات تربيت بدنى استان كلستان نسبت به

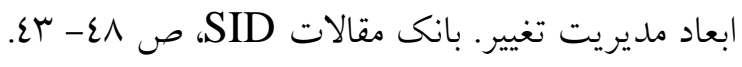

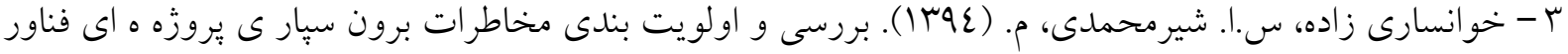
مطالعٌُ موردى: يروزه هاى زيرساخت فناورى اطلاعات و ارتباطات)، نشر يهُ (ICT) اطلاعات و ارتباطات مديريت

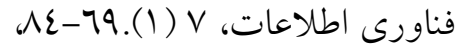

ع- رضايى، مسعود (1) (1). نظريه هاى رايج درباره يذيرش فناورى اطلاعات و ارتباطات، فصلنامه يزوهشهاى

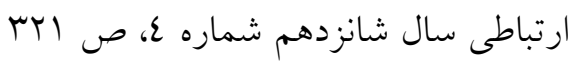

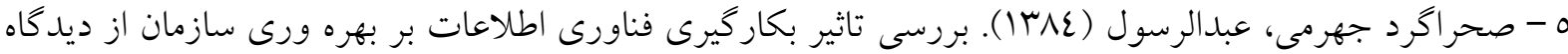

مديران يايان نامه كارشناسى ارشد دانشكده مديريت و حسابدارى دانشخاه شهيدبهشتى تهران، ص V. 7 - صنايعى، على (rar(1). (اتحليل موانع به كارگيرى فناورى اطلاعات در ادارات ورزش و جوانان استان فارس با

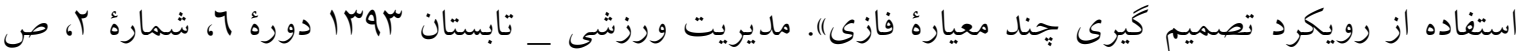




$$
\begin{aligned}
& \text { V - فيروزيان، محمودو همكاران.(1) (1). عوامل مقاومت كاركنان در برابر برنامه هاى بهبود (تغيير) سازمانى (مطالعه } \\
& \text { موردى). دو ماهنامه مديريت: شماره بr ا و ع ا. صفحه } 7 .
\end{aligned}
$$

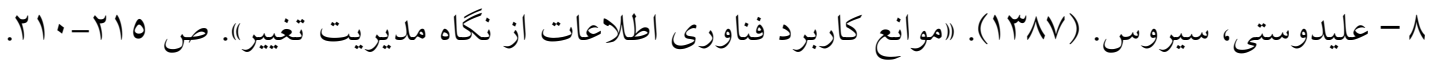

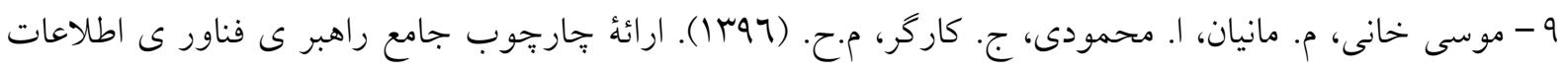

$$
\begin{aligned}
& \text { وبومى سازى آن براى صنعت خودروى ايران (مطالعهُ موردى: مادرشركت خودروى اطلس)، نشرئُ مديريت } \\
& \text { فناورى اطلاعات. ص بعاع-170 }
\end{aligned}
$$

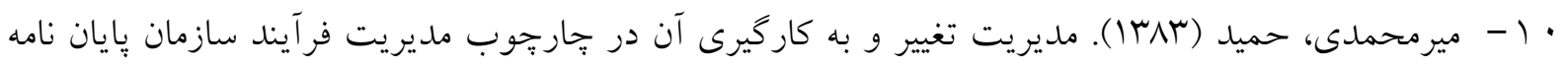

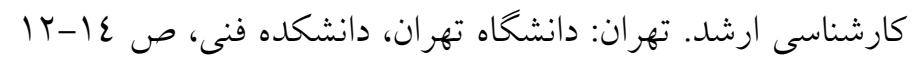

$$
\begin{aligned}
& \text { (ا - نفرى، ندا (•وr1). طراحى مدل يذيرش فناورى اطلاعات در شركت ملى كاز ايران بر اساس مدل يذيرش } \\
& \text { فناورى، بانك مقالات SID، ص 1- } \\
& \text { Y ا - نورى، ابوالقاسم (IrVq). مقاومت در برابر تغيير و شيوه هاى برخورد با آن. تهران: مركز آموزش مديريت } \\
& \text { دولتى، }
\end{aligned}
$$

13- Abdel-Ghany, M. (2014). Readiness for change, change beliefs and resistance to change of extension personnel in the New Valley Governorate about mobil extension. Annals of Agricultural Science, 59(2), 297-303

14- Akram, M. S. (2005). Managing Changes to Service Oriented Enterprises. MA thesis, Faculty of the Virginia Polytechnic Institute and State University, US

15- Armenakis, A. Bernerth, J. Pitts, J. \& Walker, H. (2007). Organizational changerecipients' beliefs scale: development of an assessment instrument. The Journal of Applied Behavioral Science, 43(4), 481-505

16- Barbaroux, P. (2011), Adesign-oriented approach to organizational change: insights from a military case study. Journal of Organizational Change Management. Pp 14-17

17- Bain \& Company Report.(2015), report management Tools \& Trend 2015. available at: www.bain.com/management tools/BainTopTenTools/default.asp

18- Bohene, R. (2012). Resistance to organisational change: a case study of Oti Yeboah Complex Limited. International Business and Management, 4(1), 135-145.

19- Brown, D. \& Wilson, S. (2005). The Black Book of Outsourcing: How to Manage the Changes, Challenges, and Opportunities, 1th edition, John Wiley \& Sons, Inc. Hoboken, New Jersey.

20- Chuttur, Mohammad(2009),Overview of the Technology Acceptance Model:Origins, Developments and Future Directions, Working Papers on Information Systems.Pp 1-14

21- Davis, F. (1989). Perceived usefulness perceived ease of use, and user acceptance of information technology. MIS Quarterly, (13, 3), 3-5.

22- Dehning, Bruce, and Vernon J. Richardson. (2002). Returns on investments in information technology: A research synthesis. Journal of Information Systems 16 (1): Pp 730. 
23- Dibbern, J. Goles, T. Hirschheim, R. \& Jayatilaka, R. (2004). Information Systems Outsourcing: A Survey and Analysis of the Literature. Data Base for Advances in Information Systems, 35(4), 96-102.

24- Grover, V. \& Teng, J. T. (1993). The decision to outsource information systems functions. Journal of Systems Management, 44(11), 34-38.

25- Kwahk, K. \& Lee, J. (2008). The role of readiness for change in ERP implementation: Theoretical bases and empirical validation. Information \& Management, 45(7), 474 - 481.

26- Lines, B. Sullivan, K. Smithwick, J. \& Mischung, J. (2015). Overcoming resistance to change in engineering and construction: Change management factors for owner organizations. International Journal of Project Management, 33(5), 1170-1179.

27- Oreg S.(2013); Personality, context, and resistance to organizational change. European Journal of Work and Organizational Psychology 2013; 15(1): Pp 73-101.

28- Prosci.(2003) (ADKAR). A model for change management, change management center.

29- Ramanathan, T.R. (2009). The role of change management in implementing the offshore outsourcing business model: a procedural view. Service Business, 3, 341-358

30- Rusly, F. Corner, J. \& Sun, P. (2012). Positioning change readiness in knowledgemanagement research. Journal of Knowledge Management, 19(6), 1204

31- Sarayeh B, Khodair H; (2013), Comparative study: The kurt Lewin of change management. International of computer and IT.2279 - 0764,v 02. Pp 6-9

32- Schneider, S. \& Sunyaev, A. (2016). Determinant factors of cloud-sourcingdecisions: reflecting on the IT outsourcing literature in the era of cloudcomputing. Journal of Information Technology, 31(1), 1-31

33- Sun, H. \& Zhang, P. (2006). The Role of Moderating Factors in User Technology Acceptance. Int. J. Human-Computer Studies, 64, Pp 53-78

34- Venkatesh, V. \& Davis, F.D. (2000). A theoretical extension of the technology acceptance model: four longitudinal field studies, Management Science, 46 (2), Pp 186-204.

35- Willcocks, L.P. \& Lacity, M.C. eds. (2016). The new IT outsourcing landscape from innovation to cloud services. Switzerland: Springer

36- Worley, C. \& Mohrman, S. (2014). Is change management obsolete? Organizational: Dynamics, 43(3), 214-224

37- Wu, S. Straub, D. \& Liang, T. (2015). How information technology governance mechanisms and strategic alignment influence organizational performancelnsights from a matched survey of business and it managers. MIS Quarterly3,39(2),497-5718

38- Ziemba E; (2015), change management in information systems project for public organizations in Poland.interdiciplinary journal of information knowledge and management.10, Pp 47-62. 